\title{
Erratum to: Living with orofacial conditions: psychological distress and quality of life in adults affected with Treacher Collins syndrome, cherubism, or oligodontia/ectodermal dysplasia-a comparative study
}

\author{
Amy Østertun Geirdal · Solfrid Sørgjerd Saltnes • \\ Kari Storhaug • Pamela Åsten · Hilde Nordgarden • \\ Janicke Liaaen Jensen
}

Published online: 6 December 2014

(C) Springer International Publishing Switzerland 2014

\section{Erratum to: Qual Life Res}

DOI 10.1007/s11136-014-0826-1

One of the affiliations of the second author, S. S. Saltnes, is missing in the original publication. It has been included in this erratum.

The online version of the original article can be found under doi:10.1007/s11136-014-0826-1.

\footnotetext{
A. Ø. Geirdal ( $₫)$

Faculty of Social Sciences, Oslo and Akershus University

College of Applied Sciences, Oslo, Norway

e-mail: amy-ostertun.geirdal@hioa.no
}

S. S. Saltnes · J. L. Jensen

Department of Oral Surgery and Oral Medicine, Faculty of

Dentistry, University of Oslo, Oslo, Norway

S. S. Saltnes · K. Storhaug · P. Åsten · H. Nordgarden

TAKO-Centre, Lovisenberg Diakonale Hospital, Oslo, Norway 